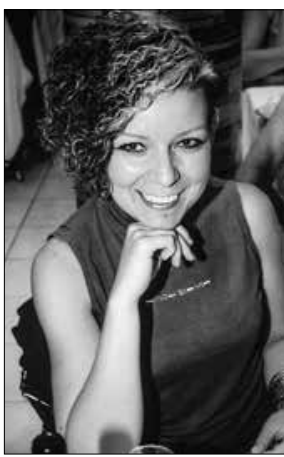

\title{
LINA GOTAUTE
}

Lietuvos kultūros tyrimų institutas

Lithuanian Culture Research Institute

\section{ČANBUDIZMO ESTETINIŲ IDEALŲ ATSPINDŽIAI JAPONIŠKOJE WABI-SABI ESTETIKOJE}

\author{
Reflections of Aesthetic Chan Buddhism Ideals \\ in Japanese Aesthetics of wabi-sabi
}

\begin{abstract}
SUMMARY
The essence of wabi-sabi that emerged under the Chan Buddhism tradition stemming from China has influenced the concept of aesthetics, which is an everyday feature of life in Japan. The purpose of this article is to distinguish the most characteristic features of this aesthetic form. It focuses on the main aspects of wabi-sabi in both everyday life and various fields of artistic expression in Japan. By analyzing fundamental texts of Zen it seeks to uncover possibilities for this aesthetic tradition to solve problems of the relationship between a person and reality in the global world that is taking place today.
\end{abstract}

\section{SANTRAUKA}

Estetikos, kuri Japonijoje yra neatsiejama kasdienio gyvenimo dalis, sampratai didžiausią poveikį padarè iš Kinijos pasklidusi čanbudizmo estetikos tradicijos įtakoje susiformavusi savita japonų wabi-sabi estetika. Šio straipsnio tikslas yra išskirti šios savitos estetikos būdingiausius bruožus. Jame pagrindinis dèmesys sutelkiamas ị pagrindinius wabi-sabi raiškos aspektus kasdieniame japonų gyvenime ir ịvairiose kūrybinès veiklos srityse. Remiantis pamatinių dzen tekstų analize, siekiama atskleisti šios estetinès tradicijos potencines galimybes spręsti šių dienų globaliajame pasaulyje iškylančias žmogaus santykio su tikrove problemas.

\section{IVADAS}

Didingų kinų kultūros tradicijų są- je visų pirma siejasi su estetine tradicilygotas dzenbudizmas (dzen) Japonijo- - ja, kuri ir šiais laikais aptinkama japonu

RAKTAŽODŽIAl: japonų tradicinė estetika, čan estetika, dzenbudizmas, dzen estetika, wabi-sabi, panteizmas. KEY WORDS: traditional Japanese aesthetics, chan aesthetics, zen buddhism, zen aesthetics, wabi-sabi, pantheism. 
buityje, mąstysenoje, grožio supratime, mene, architektūroje ir kitose kultūros srityse. Kartu su iš Kinijos atkeliaujančiais nuo mongolų persekiojimo bėgančiais vienuoliais Japonijoje isitvirtina nauja asketiška čanbudistinė (čan) pasaulèžiūra, kuri skleidžiasi kasdieniame žmonių gyvenime, ìvairiose kultūros ir meno srityse prarasdama abstraktų metafizini pavidalą ir ižvelgia dieviškąą prigimti kiekviename žmoguje bei gyvyje. Kinų vienuoliams čanbudistams pasiekus Japonija, čan Japonijoje buvo pavadintas dzen. Šio mokymo negalime sieti vien su religija ar filosofija, tai greičiau su daoizmu, vedanta ar joga panašumų turintis pasaulio suvokimo ir gyvenimo būdas, žvilgsnis ì gyvenima, neịtelpantis i Vakarų mokslo sukurtas sistemas, kadangi apima vientisumą tarp žmogaus, kosmoso, ieškojimų, išsivadavimo.

Iš kinų čan estetinių idejų lauko išplaukiantis sinkretiškas dviejų pamati- nių kategoriju wabi-sabi junginys imliai apibūdiną tradicinę japonų estetinę kultūrą, kurioje dar viduramžiais skleidžiasi jai būdingos, su japonų kasdieniu gyvenimu, menais, etinėmis ir estetinėmis vertybėmis susijusios nuostatos. Wabi perteikia švarią, natūralią erdvę, asketiškumo ir natūralumo patrauklumą. Gyvenimas be materialaus pasaulio prievartos yra itin aukštas idealas, išlaisvinantis žmogų ir atveriantis jam kelią i dvasingesni pasaulio suvokimą. Tai gyvenimiškoji filosofija, randanti neatsiejamą atsaką kitoje estetinejje kategorijoje sabi, kuri skatina atkreipti dèmesi i trumpalaikiškuma, laikinumą, nuolatinį kitimą ir tai, jog viskas kada nors baigiasi mirtimi. Visa tai kartu siejasi su natūraliu gyvenimu, jo tèkme, jègų šaltiniu dabartyje - tai ištisos kultūros idealas, kardinaliai besiskiriantis nuo Vakaru pasaulio gyvenimo prasmès suvokimo, būties filosofijos bei tuo pačiu kuriantis wabi-sabi gyvenimo principą.

\section{WABI-SABI ESTETIKOS IŠKILIMAS DZENBUDIZMO MĄSTYMO TRADICIJOJE}

Kamakuros epochoje Japonijos kultūra yra visiškai priklausoma nuo svarbių socialinių pokyčių, kadangi įsivyrauja naujas karinio pobūdžio samurajiškas valdymas ir su tuo siejama imperatoriškosios giminės, aristokratijos bei religijos ir meno išlikimo bei su tuo susijusių pokyčių aplinka. Vyriškoji karingoji kultūra tampa dominuojančia, atitinkančia naująsias gyvenimo sąlygas bei siejama su vis populiaresne tampančia dzenbudizmo tradicija, kuri imponuoja naujiesiems valdovams, kadangi atmeta kos- minio Budhos egzistavima, susieja Absoliutą su žmogumi, kuris turi dieviškąją prigimtí, todèl jo potencialios galimybès yra neišmatuojamos. Svarbiausiu dalyku tampa žmogaus pirmaprade prigimtis bei užduotis ją pažinti.

Idomu, jog dzen vienuoliai patraukia link gamtos, atsisakoma miestu, vienuolynai statomi įstabiose vietose, arčiau upokšnių, kalnų, girių apsupty. Kadangi samurajams buvo svarbūs pragmatiniai interesai, „vienuoliai ne tik pagerbdavo mirusiųjų savo globejjų atminimą dzen- 
budistinėmis apeigomis, bet ir rašydavo ju vardu dokumentus, atstovaudavo karių vyriausybei užsienio diplomatijoje ir priimdavo finansinę paramą vadinamiesiems Penkiems vienuolynams - ypatingomis privilegijomis apdovanotoms abatijoms Kamakuroje, kartu susitaikydami su neišvengiamu pasaulietinès valdžios diktatu. Ilgainiui net dvasininkai pirmenybę èmè teikti ne tiek religinių dogmu saugojimui, kiek iš žemyno dzenbudistiniais kanalais atkeliaujančios kultūros diegimui Japonijoje ${ }^{\mu 1}$, tad naujoji srovè igavo dominuojančiosios poziciją.

Feodalinè santvarka kultūrą grindžia kitokiais idealais nei Heiano epochoje vystyta pasaulěžiūra: rafinuotumą, eleganciją („moteriškosios kultūros“ pradą) keičia samurajiškos ištikimybès klanui, atsidavimo šeimai, vasališkumo idejos, paremtos Bushido kodeksu, garbès svarba, griežta hierarchija, pareigos jausmu. „Rigoristinei samurajų pasaulèžiūrai buvo artimi daugelis dzen išpažinejuc idealu, ypač vidinès tvarkos, asketiško gyvenimo, tvirtos dvasios, kūno ir ugdymo reikalavimas. ${ }^{\prime 2}$

Japonų budizmo naujoji srovè masino Šiogūnato karius, jie tapo pagrindiniais finansuotojais iš Song imperijos atkeliaujantiems vienuoliams - tikètina, jog tai siejosi su ideologinès tapatybės paieškomis, noru parodyti, jog Kamakuros laikotarpis privalo aiškiai skirtis nuo to, kas buvo siejama su Kiotu, t. y. senuoju imperatoriaus valdžios miestu. Dzenas, pats nesitapatinęs su jokia konkrečia mokykla, pirmiausia iš kitų išsiskyrè didele pagarba gamtinių daiktu prigimčiai - miškams, uoloms, upès tėkmei, tvenkiniams, samanoms, visoms gyvy- bės formoms. Siekis ir gebejimas pamatyti savo būties prigimti, natūralios energijos išlaisvinimas randant savąji kelią iš suvaržymu i tikrosios prigimties suvokimą - toks yra pagrindinis dzen tikslas, išreiškiamas savoka satori (nušvitimas).

Vienio išgyvenimas kontempliuojant gamtą dzenbudizmo vienuolius neišvengiamai vedè prie paprastumo, atsisakymo viso, kas nèra būtina, neturi didelès reikšmès. Galiausiai per asketiškojo paprastumo kelią išsikristalizavo pagrindiniai dzen estetikos principai. Galima išskirti kelis pagrindinius dzenbudizmo mokytojus: Eisai (1141-1215), ikūręs Rinzai shu pakraipa, tebeegzistuojančią iki šiol, bei Dōgen (1200-1253), pradejjęs vystyti Sōtō shū atšaką (tebegyvą XXI a.), pirmas dvasinis dzenbudizmo centras buvo vienuolio Daito ikkurtas Daitoku-ji vienuolynas. Svarbu pažymèti, jog Kamakuros laikotarpiu dzen mokymas turèjo dvejopa poveikị (priklausomai nuo to, kurioje Šiogūnato vietoje gyveno tuometiniai daimio): šiaureje ir pietuose plito Sōtō shū mokymas, kuris palaike idèją elgtis dorovingai, palaikyti atsakomybès už savo poelgius svarbą, aukštino pagarbą nelaimingiesiems - tai siejosi su poezija, estetika, religine filosofija, kaligrafija. Tuo tarpu didžiojoje šalies dalyje vyravo Rinzai atšakos mokymas, pabrèžęs griežtą auklëjima, vidinę drausmę, tikslo siekima, savikontrolę. Savaime suprantama, jog vienos ir kitos savybės tapo samurajiškojo laikotarpio vertybiu sistemos dalimi, veikè Bushido (Garbès) kodeksa, vystėsi pagrindinius aspektus atspindinčios dzen estetikos, arbatos ceremonijos, japoniškuju sodu, meno kūrybos tradicijos. 
Iki pat šių dienų gili japonų minties tradicija, iškilusi XIV a., kaip reakcija prieš tuo metu vyravusią gausaus puošnumo ir ornamentikos estetika, yra tai, kas įvardijama sąvokomis wabi-sabi. Ši tradicija laikoma menu sugebèti aptikti groži netobulume bei gelmę žemiškume, visų pirma pabrèžiant autentiškumo svarbą. Svarbu pabrèžti, kad šios sąvokos yra taip giliai persmelkusios Japonijos kultūrinio gyvenimo kasdienybę, jog dažnai yra sudètinga perteikti šių žodžių reikšmę, nes vieno griežto tiesioginio vertimo paprasčiausiai nèra. Wabi estetikoje grožis suvokiamas per askezès, paprastumo, kintančios akimirkos patyrimą ir išgyvenimą. Bègant laikui wabi pamažu liejasi su sabi - be askezès ir vienatvès, pradedama vertinti ir senejjimo proceso teikiama ramybè.

Nors leksinius vienetus wabi ir sabi išversti nèra paprasta, pirmaprade savo prasme žodis wabi nusako gyvenimo gamtoje vienišuma, sąmoningą atsiribojimą nuo visuomenès. Ši sąvoka siejama ne tik su griežtu paprastumu, šviežumu ar tylumu, tačiau taip pat ir su natūraliais bei žmogaus sukurtais objektais, lygiai kaip ir su suprasta elegancija. $S a-$ bi reiškia 'šaltas', 'liesas' arba 'išdžiūvęs'. Maždaug XIV a. šios prasmės ėmė keistis, pereinant prie pozityvesnių sąvokos konotacijų ${ }^{3}$.

Pasak Leonardo Koreno, wabi-sabi gali būti apibrèžiamas kaip „labiausiai išsiskiriantis ir būdingiausias tradicinio japonų grožio bruožas, ir jis užima tokią pat vietą japonų estetinių vertybių panteone, kaip kad graikų grožio ir tobulumo idealai Vakaruose “4 . Andrew Juniperis pastebi, kad ,jeigu objektas ar išraiš- $\mathrm{ka}$, giedrios melancholijos ir dvasingumo jausmas gali susitelkti mūsų viduje, tuomet galima sakyti, kad tas objektas yra wabi-sabi“" .

Richardas Powellas teigia, kad „wabisabi ugdo visa, kas yra autentiška, pripažindamas tris paprastas tikroves: niekas neužtrunka, niekas neužbaigta, ir niekas nèra tobula"6. Taro Gold wabi-sabi apibrèžia kaip "grožio ir netobulumo išmintį "

Wabi-sabi estetikos bruožai apima asimetrija, šiurkštuma, paprastuma, išraiškos taupumą ir talpuma, kilnuma, intymuma, gamtos daiktų ir procesų tarpusavio sąveikos integralumą. Bègant amžiams, patyrus kinų meno ir budizmo ìtaka, wabi-sabi natūraliai išsivystè i i išskirtinai japonišką kultūros estetikos idealą.

Wabi-sabi estetikoje aiškinama, kad grožis yra dinamiškas dalykas, jis gali spontaniškai pasirodyti bet kurią akimirka, priklausomai nuo tinkamų aplinkybių, situacijos ar žiūros kampo. Todèl grožis yra sąmonès būsenos pokytis (permaina), išskirtinè poetinès nuostabos akimirka.

Kaip pažymi garsusis japonų architektas Tada Ando (What is wabi-sabi?), šitaip visų pirma apibrėžiamas paprastumas, lètumas bei tam tikra netvarka, jeigu joje atsiskleidžia minètasis autentiškumas: „Wabi-sabi yra sendaikčiu turgūs, bet ne prekybos sandèliai; sendintas medis, bet ne laminuotos grindys; ryžių popierius, bet ne stiklas. “8 Kitaip tariant, ",taip švenčiami îskilimai ir plyšiai bei visi kiti ženklai, kuriuos laikas, oras ir rūpestingas naudojimasis paliko po savęs"

Savo knygoje Praise of Shadows Janichiro Tanizaki mėgina paaiškinti japonu požiūrị i šviesą ir tamsą, tvirtindamas: 
„mes ne nemėgstame visko, kas šviečia, bet teikiame pirmenybę mąslumui vietoj seklaus ryškumo, drumzlinai šviesai, kuri ar akmenyje, ar dirbinyje rodo senovès blizgesį “10. Šie žodžiai tiksliai išreiškia tokios estetikos dvasią.

Wabi-sabi primena, kad visi esame laikinos būtybès šioje planetoje, mūsų kūnai, lygiai kaip ir materialių daiktų pasaulis aplink mus, yra grižzimo ị dulkes procesas. Ciklinis gamtos esinijos gimties, erozijos ir suirimo ratas persmelkia viską. Per wabi-sabi mes mokomès ivertinti tiek didybę, tiek melancholija kurią taip pat neišvengiamai aptinkame prabègančio laiko tèkmèje. Tai kilnus, pakankamai tylus ir nedeklaruojamas grožis, kuris kantriai laukia, kad būtų atrastas. Tuo pačiu tai yra brandžiai turtingas grožis, kuris, ji išvydus, apstulbina, bet nèra akivaizdus. Fragmentiškos tokio grožio atverties akimirkos metu iškyla gilus suvokimas, kad detalè perteikia visuma, o visumoje atsiskleidžia detalès reikšmè.

Wabi-sabi iškèlimas individualiame gyvenime nereikalauja nei pinigų, nei ypatingos praktikos ar igūdžių. Užtenka mąstymo, kuriame įvertinamas besikeičiantis grožis, drąsa nebijoti nuogumo, gebejimas priimti daiktus tokius, kokie jie yra. Sąmoningai vengti ornamentinès puošybos. Jis priklauso nuo sugebejjimo sustoti ir îsižiūrèti i daiktus, atrasti pusiausvyrą tarp veikimo ir savojo buvimo vertès pajautimo.

Wabi-sabi gali priklausyti ir šiurkšti žaliava, minimaliai pakeisti gamtiniai daiktai, lygiai kaip ir gamtoje atsiveriantys subtilūs atspalviai. Visuose šiuose dalykuose atsiveria mūsų universalusis ilgèjimasis išminties, mūsų autentiškumas ir bendrai išgyvenama istorija.

\section{DZENBUDISTINĖS PASAULĖŽIŪROS RYŠYS SU WABI-SABI ESTETIKA}

Dzen mokymas Japonijoje priartèja prie žmonių buities, kasdienybės, tampa nebe sudètingų konstrukcijų ir abstrakčių samprotavimų, o karių visuomenei pritaikytų meditacinių praktikų, nuolatinio savęs tobulinimo, satori siekimo apraiška. Samurajams įtiko naujoji religija, teikianti prasmę dzen auklejimo ir psichologinių praktikų sistemai mondō, kuri realizavosi kōanu praktika, skatinančia metaforini, intuityvų mąstymą. Svarbus tampa autentiškas, originaliai išgyventas patyrimas. Metaforinis, intuityvus satori siekiančiojo mąstymas išlaisvina jo juslines galias, keliami nauji uždaviniai, nauji išbandymai, kurie užgožia visas pašalines mintis, mąstymas išsigrynina, apsi- valo nuo nereikalingų detalių ir pasiekiamas vientisas ryšys tarp žmogaus būties, jos esmès, žemiškosios egzistencijos bei kasdienès patirties.

Aprašytoji situacija atspindi vieną iš pamatinių dzen bruožų - neišsakomumą. Žmogaus dvasia yra tiek sudètinga ir kupina gausybès neprognozuojamu potencijų, jog priartina praktikuojantiji prie bekraštės būties, kurios esmę suvokiantis žmogus negeba suteikti jai konkrečios formos ar apibūdinimo ir jo patyrimai tegali reikštis intuityviai pasireiškiančia kūrybine galia, kurioje vyrauja užuominos, metaforos, gausybè išgyvenimų, priartinančių ji prie tikrosios bekraštès būties, kuri, kaip tikèjo dzen 
meistrai, gimsta iš visa apimančios nebūties, tuštumos, skendinčios beribiame būties procesų sraute. Šitaip svarbi kontempliacinè būsena pasiekiama pasyvios sèdimosios meditacijos būdu, ji išreiškiama, kuriant poezija, užsiiminėjant kaligrafija, tapant ar apmąstant žmogaus būties laikinuma, kaip ir tai perteikiant $N o ̄$ teatro scenoje; „Kamakuros epochos kultūra, išskyrus savitus feodalinius bruožus, yra ne paprasta Kamakuros kultūra, bet Heiano kultūros tęsinys feodalinèje valdžioje ${ }^{\text {"11 }}$. Izžvelgtinos tiesioginès sąsajos su yougen kategorija, kuriai būdingas subtilus giliamintiškumas - ji siejasi su sabi per šios kategorijos išreiškiamas neišsemiamas amžinybès ir tuštumos galimybes. Kita vertus, sabi prieštarauja yougen savo apraiškomis realiuose, artimuose, apčiuopiamuose daiktuose bei akivaizdžiuose gamtos bei gyvenimo reiškiniuose.

Aptartasis reiškinys siejasi su wabisabi estetika, kurioje abi sąvokos dažnai vertinamos kaip nedalomos. Tačiau wabi konceptas itin tiksliai atspindi makoto (t. y. paprasta, natūrali, pirmykštė tikrovè, realybè), kuris kontrastuotų su aware patetiškumu, idealumu ir sąmoningu rafinuotumu, tačiau sudaro vieni su sabi asketiškumu bei natūralumu. Juk būtent wabi išreiškia kūrybinès energijos jẻga, kuri pesmelkia visa, kas gyva ir negyva. Kūrybinis potencialas tiesiogiai susijęs su bekraštès būties paieškomis, grižimu prie pirmapradžių tiesu, intuityvaus žmogaus ir ji supančio kosmoso vienio suvokimo. Budistinis vienovès su visu pasauliu idealas neretai siejasi su prieštaravimais, iškylančiais tarp žmogaus ir realios aplin- kos, kasdienès būties, kurioje egzistuoja neteisybè, smurtas, nelaimès.

Būtent Sōtō mokykla atmetè diskursyvų mąstymą, orientuodamasi i intuiciją, estetinę užuominą, neišsakymą. Buvo tikima, jog net ir labai turtinga dvasinę patirti galima ,italpinti“ keliose kaligrafinèse struktūrose, minimaliame tapybiniame ìvaizdyje ar keliuose haiku žodžiuose. Jau nekalbant apie tai, jog Nō teatre tai dažnai apibrèžiama metafiziniu reginiu, atveriančiu visuotinio sielvarto skaudulius. Vidiniai išgyvenimai yra inspiruojami metamorfozès.

Svarbu pažymèti, kad, dzenbudistų manymu, intelektas nèra pakankamas ginklas spręsti galutinès tikrovès klausimą. Tiesa, jis kelia toki klausima, tačiau nereiškia, kad yra pasirengęs atsakyti i ji. Klausimo kèlimas iš tikruju parodo troškimą rasti kažką pirminio, kuri laikydami pagrindu, mes galètume kurti savo žmogišką likimą: „Intelektas žvelgia iš išorès, perima "objektyvų“ daiktų

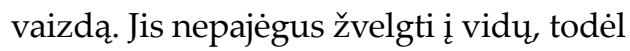
neapčiuopia daiktų ju esmëje. Jis mėgina pasiekti apjungianti pasaulio vaizdą tuo, kas yra žinoma kaip objektyvus metodas. Šis objektyvus metodas gali veikti gerai, bet tik tuomet, kai vidinè žiūra yra atribojama." 12 Tokia Vakaru mąstymo tradicijoje isitvirtinusi subjekto ir objekto perskyra, dzenbudistų požiūriu, yra vienas didžiausių kliuvinių kelyje ì tikraji savęs ir daiktų esmès supratima, todèl yra nepriimtina ir kritikuotina. Pirminė ar galutinė tikrovė nèra anapus ar nutolusi kažkur kitur. Viskas prasideda nuo čia ir dabar, priešingu atveju tikrasis santykis su tikrove yra praranda- 
mas. Aplinkos situatyvumo, nepakartojamumo ir akimirkos vertingumo iškèlimas nepaprastai svarbus visai japonu jausenai, ypatingai aiškiai atsiskleidžiantis wabi-sabi estetikoje.

Wabi-sabi grožio supratime ypatingai svarbus tampa iš daoizmo ir čan (dzen) estetikos perimtas non finito, tai yra „neišsakymo principas", kuris teigia ",kad bet koks išbaigtumas pažeidžia natūralia gyvenimo tékmę ir siejasi su sąstingiu, mirti$m i^{\prime 13}$. Savo ruožtu "neišbaigtumo poetika skatina atvira diskursa, subtilias estetines užuominas, nuolatini žaisma simbolinemis prasmèmis, kaukemis, ženklais, vienareikšmingumo vengima" ${ }^{\prime 14}$.

Kitas labai svarbus dzenbudizmo aspektas - Tuštumos (sunyata) konceptas. Jis apibrèžia Absoliutaus prado esmę, tai yra "neišsenkamumo" simbolis, apibūdinamas beformiškumu, negirdimumu, tuščiu plotu, neveikimo būsena, tyluma, pauzėmis. Tai itin ryškiai reiškiasi dzen vienuolynuose kurtuose tapybos kūriniuose - tuščio ploto reikšmè, muzikoje pauzès, tylumos momentas, teatre - tyluma spektaklio veiksme, poezijoje - tyla, pauzè. Kuo ilgiau trunka tyluma, tuo stipresnes emocijas patiria suvokèjas, tai yra bežodžio meno raiška, kuri suvokiama juslèmis, išgyvenama metafiziškai.

Nepaisant tam tikrų skirtumų, būdingų dzenbudizmo mokykloms, nušvitimo (satori) patirtis, kuri yra aukščiausias dzen praktikavimo tikslas, pasiekiama tik gebant betarpiškai issižiūrèti ì tikrovę, daiktu ypatingumą. Paties daiktiškumo šaltiniu laikoma tuštuma (sunyata), kuri laikoma pozityvia, o ne negatyvia galia. Tuo pačiu „dzenas teigia visiško išsivadavimo mokymą - išsivadavimo tiek nuo pasaulietiškumo ir sakralumo, tiek nuo moralès ir religijos, tiek nuo teistinès religijos, tiek nuo ateistinio nihilizmo"15. Kita vertus, nors dzenbudistų požiūris i tuštumą transcenduoja tiek sekuliaruma, tiek sakraluma, tuo pačiu metu dzen yra tiek sekuliarus, tiek sakralus: „Pasaulietiškumas ir sakralumas yra paradoksaliai tapatūs, einantys kartu kaip dinaminè visuma, už kurios tèra niekas. " ${ }^{16}$ 'Niekas' ar 'tuštuma' apibrèžiama kaip kažkas, esantis anapus savasties, dzen meistrų požiūriu nėra tikrasis „niekas" ar ",tuštuma“, nes tikroji „,tuštuma“ yra tai, ko neimanoma paversti objektu. Dèl tos pačios priežasties „tuštuma“ yra ir tikrojo subjektyvumo pagrindas. Sunyata galima išgyventi, išsilaisvinus iš samsaros (gimimo, mirties, prisikèlimo ciklo), ji pabrèžia, kaip stipriai šiame pasaulyje viskas susiję gausybès vykstančiu procesų tèkmejje. Išsilaisvinama iš nuolatos vykstančių atgimimo ratų, nes tuštuma yra beribė, joje viskas atsiranda ir vèl sunyksta.

Pasak subtilaus XX a. dzen tradicijos žinovo T. D. Suzuki, esminis Zen metodas jau nuo pirmojo sąmonès prabudimo prasideda nuo visų psichologinių turinių išsivalymo, atskiriant savasti nuo jos psichologinių puošmenų - moralinių, filosofinių ir dvasiniu, - kuriais ji nuolatos save dabino ${ }^{17}$. Antra vertus - pažymi toliau vienuolis, - „ši savastis, išvalyta iš visų savo vadinamųju psichologinių turinių, nèra tokia 'tuštuma', kaip kad šis žodis iprastai suprantamas. Išvalyta savastis yra elementari psichologinè savastis, apvalyta nuo jos geocentrinès vaizduotès. Ji yra tokia pat turtinga turiniu kaip ir prieš tai; iš tiesu ji yra turtingesnè nei prieš tai, nes dabar ji savyje talpina 
visą pasauli, užuot turèdama pasauli, stovinti priešais ją"18. Taip išvalyta sąmonè mėgaujasi sau tinkamo, absoliučiai nepriklausomo, autentiško, autonomiško ir aistrų nepažeidžiamo buvimo esatimi.

Tuštuma apibrèžia beribị, begalini potencialą ir ji atitinkančias galimybes; tai yra jèga be vektoriaus, be modulio, „,̌̌vari lenta", kuri pasiekiama nuolatiniu zazen (meditacija), apmąstoma protu lygiai taip pat kaip ir pajaučiama, plytinti už racionalumo ir iracionalumo. „Tuštumos" konceptas dzenbudizme yra perimtas iš budizmo ir vedų, skirtumas tik toks, jog senieji budizmo meistrai stengèsi sunyata paaiškinti, o dzen atstovai atsisakė aiškinimu, teigdami, jog geriausias tuštumos aiškinimas yra tylejjimas arba alegoriniai kōan. Tuštuma yra visa ko pradžia, ji garbinama, būtent menais ieškoma būdų jai išreikšti, išryškinti jos groži (ne meno kūrinių, kaip būtų galima suprasti Vakaruose), dekoratyviosios detalès slepia esmę, ją stengiamasi suvokti širdimi (kokoro).

Geriausiai tuštumos estetinę prasmę bei sąsajas su wabi-sabi atspindi tušti kambariai su minimaliu baldų kiekiu, tuštumos kupini paveikslai - mažas piešinèlis baltos drobès kampe; tuštuma išsiskiria ne todèl, kad tampa išsiskiriančia tokioje vaizdavimo erdvèje, o todèl, kad ji igyja itin gilią prasmę praktinejje plotmeje, reikalinga atitinkama patirtis ją perprasti. Tuo pačiu prasiplečia ir filosofinis jos suvokimas.

Nepasitikejjimas verbalinėmis raiškos priemonėmis, keliant tiesos pažinimo klausima, dzen mąstymo tradicijoje atveria platų horizontą meno kūrinių ver- tès sureikšminimui. Menas iškeliamas kaip tam tikra mediumo terpè, kurioje Tiesos ivvykis apčiuopiamas formas igauna pačiame individo intuityvių galių sutelkimo ir išreiškimo meninèmis priemonemis procese, kuriame daug didesnę svarbą igyja tyla ir meditacinès, psichinę energiją disciplinuojančios praktikos.

Itin svarią reikšmę dzenbudizmo mokyme turi gamtos kultas bei estetizuotas panteizmas. Japonų gamtos pajautimas turejjo be galo stiprią itaką dzenbudizmo isigalejimui, formavo jo vertybes, suteikè daug gilesnę mąstymo tradicija, panteistinè pasaulëjauta tapo neatsiejama dzenbudizmo dalimi, kadangi ši budizmo atšaka priima gamtą kaip ypatingai gerbiama, laiko ją šventa. Svarbus dzen santykis su gamta, jos reiškiniais: nedemonstruojamas žmogaus pranašumas gamtos atžvilgiu, siekis ją užvaldyti, pagrindinis tikslas - sugyventi su gamta, siekti kiek galima gilesnio dvasinio ryšio su ja, išgyventi harmoniją ir îsilieti i gamtos ciklų kaitą bei pritaikyti gamtos ittaką kūryboje, kasdieniame gyvenime, žavètis ja. Intuityvi pasąmonès veikla dažnai taip pat yra gamtos pasaulio išraiška, padedanti grižti prie pirmapradžių verčių, pasaulio ir supančių daiktų gilaus suvokimo. Tai kuria natūralumo kultą bei estetinès vertès svorị meno kūriniuose, kasdieniuose daiktuose ir erdvès planavime.

Dzen principai su wabi-sabi estetika siejasi besikeičiančio gamtos grožio plotmejje, siekiama perteikti tobulumą netobulomis, natūraliomis gamtos formomis, žmogus kontempliuoja gamtos groži, reflektuoja būties problemas vienyje su gamta, jos jègomis. Tokioje aplinkoje 
gimsta kūrèjas - ir visai nesvarbu, ar jis yra ypatingo talento tapytojas, ar eilinis ryžių augintojas, gebantis žiesti puodus... Esmè priimti kūrybines galias širdimi (kokoro), susitapatinti su kūrybos objektu, rasti darną su aplinka, vidinę ramybę su savimi ir Visata, kurios energija persmelkia kiekvieną, gyvenanti sudievintos gamtos apsupty ir paklūstanti jos ritmui. Iracionalumas bei vitališka gamtinè jèga pajègi išlaisvinti žmogų iš būties bei buities rèmų, nuskaidrinti mintis bei susieti jas su vaizduote.

Dzenbudizme vidinès laisvès idealas bei neprisirišimas prie išorinio pasaulio tapo gyvenimišku principu ir nepakeičiama meninės kūrybos sąlyga. Absoliutus išsilaisvinimas nuo pasaulio sietinas $\mathrm{su}$ „ištirpimu“ jame, o tiesioginis atsiskyrimas - su harmonija ir giliu vidiniu ryšiu su gamta bei su visais paprasčiausiais ir nepastebimiausiais kasdienio gyvenimo pasireiškimais. Ši paradoksali būsena buvo pasiekiama išgyvenant $s a$ tori, ieškant naujos vizijos, taip pat - vidine transformacija ir grižimu ì realų gyvenimą. Sabi koncepto gilumoj slypi vidinès laisvès, proto ramybès ir gilios taikos būsenos, o taip pat ypatingojo jausmo kanjaku (ramios vienatvès), aiškios ir skaidrios vidinès tuštumos, nepriklausomybès nuo visų pasaulių ir egoistiškojo $a s ̌$ išgyvenimas. Suzuki nuomone, ta "skaidruma“ yra raktas dzen santykio su gamta supratimui, ir būtent ji gimdo meilę gamtos reiškiniams. Kitu generuojančiuoju subjektu ir ontologine kategorija, apibrèžiančia sabi, tampa laiko konceptas, kuris suteikia daiktams senovinio žavesio, patinos taurumo ir tuo pačiu pripildo juos trumpalaikiškumo, efemeriškumo ir atsitiktinumo savybèmis. Sabi nuo wabi skiriasi tuo, kad sabi apibrèžia senovès pėdsaku pažymètą grožì, kuriame slypi likimų ir ivvykių visuma, asociacijų ir prisiminimu lobynai, šimtmečių dialogai ir ju persipynimai, ritmas ir gyvenimo alsavimas bei laiko pulsas. Sabi geba akimirkoje pagauti amžinybès aida, kiekviename atskirame daikte sugebant pajausti rankų, dvasios prisilietimo ženklus, išgyvenant rezonansą su žmonių likimų ritmu.

Netobulumas tampa keliu i vidinę ramybę, nematoma panteistinė pasaulejauta skleidžiasi dzen sodų žalumoj, tikras kūrinys priverčia suvirpèti, senas, dešimtis metų skaičiuojantis įtrūkęs puodelis atspindi neikainojamus prisiminimus, o nutapytas gamtos peizažas kelia asociacijas su bėgančiu laiku. Ir viską tenka išgyventi širdimi (kokoro), pajusti dvasia, kurią turi ir akmuo, ir medis, ir vabalèlis, ir visa, kas juda nuolat besisukančiame samsaros rate. Žmogus tampa kosmoso ir kūrybinès energijos retransliuotoju, dzen išgrynina tą estetika, kuri būdinga kokoro turintiems objektams ir reiškiniams.

Gamtos kultas ir panteizmas, kurio bruožai ateina dar iš šintoizmo tradicijos dvasinio paveldo, autentiškojo kūrybiškumo polèkis, visų pirma išsiskleidžiantis nuolatinime siekyje "būti kelyje", pirmapradès pasaulio rasties iš tuštumos samprata, universalios harmonijos dèsnių pojūtis, nepaisant simetriškumo ignoravimo - tai ryškiausi dzenbudizmo tradicijos pėdsakai wabi-sabi estetikos iškilime, iki šiol formuojantys unikalų Tekančiosios šalies kultūrinį atvaizdą. 


\section{HIEROGLIFŲ RAŠTO POVEIKIS WABI-SABI ESTETIKAI}

Rytų ir Vakarų tautų kalbinėse sistemose semantinės ženklų reikšmès išsakomos ir suvokiamos skirtingai. Rytu Azijos kultūromis ir komparatyvistine problematika domèjęsis prancūzų postruktūralistas R. Barthes'as subtiliai pastebi, kad Japonijoje „prasmiu imperija yra tokia plati, tiek viršijanti kalbejjima, kad pasikeitimas ženklais išsaugoja užburianti turtinguma, paslankumą, rafinuotuma, nepaisant netgi kalbos neperregimumo, o kartais netgi dèka jo. Taip atsitinka todèl, kad kūnas čia gyvuoja, atsiskleidžia, veikia, lieka be jokios isterijos, be narcisizmo, paklusdamas grynam erotiniam judesiui, nors ir subtiliai slepiamam. Bendravime veikia visai ne balsas (su kuriuo mes sutapatiname ,asmenybès" teises; o ką jis gali reikšti? Mūsų dvasią - neabejotinai tyrą? Mūsų nuoširdumą? Mūsų prestižą?), o visas kūnas (akys, šypsena, plaukų sruoga, gestas, drabužiai) kreipiasi i jus kažkokiu vapaliojimu, čiauškimu, lemenimu, infantilumas arba atsilikimas, kuris visiškai iš nyksta apvaldant kultūrinius kodus ${ }^{\text {"19 }}$.

Per hieroglifiniam raštui būdingą ženkliškumą išskirtinę reikšmę igavę vaizdinis, kontekstualus bei situacinis japoniškų sąvokų suvokimas neabejotinai veikè ir estetinius wabi-sabi principus, kurių dẻka nèra sureikšminama aiškiai apibrèžta žodžio reikšmè, i̇sigali neišsakomumo pabrèžimas, tam tikras nepasitikèjimas racionaliai artikuliuojamais kalbiniais turiniais. Akimis neregima kūrejjo energija, kuri reiškiasi buitiškiausiuose kasdienybės daiktuose, reiškiniuose ir bendravimo ritualuose - arbatos gèrimo ceremonijoje, maisto kultūroje, kaligrafijoje, sodininkystëje, puodininkystëje, architektūrinių pastatų ypatumuose - nepasiduoda vakarietiško tipo racionaliai kalbinei argumentacijai, ką neabejotinai galime laikyti japoniškos kasdienybès estetikos unikalumu. Japonų sąvokos kokoro, reiškiančios širdi, reikšmė yra kur kas platesnè nei ją perteikia tiesioginis vertimas. Širdi, dvasią ar savasties esybę turi kiekvienas gamtinis daiktas ar reiškinys akmuo, medis, gyva būtybè, molio indas, kelio vingis. Dèl dzenbudizmo mąstymo tradicijos ittakos išgryninti estetiniai principai suteikia šiems daiktams ir reiškiniams kokoro, šitaip įkraunant i juos tam tikrą jų unikalumą išskiriančią energiją.

\section{WABI-SABI ESTETIKOS BRUOŽAI JAPONŲ KASDIENYBĖJE}

Žvelgiant i japonų kultūros tradiciją galime drąsiai tvirtinti, kad wabi-sabi estetikos formos pasireiškè daugelyje meno sričių. Dzenbudizmo mąstymo tradiciju šviesoje, kuriose ypatingas dėmesys buvo skiriamas netobulumo, nuolatinès tèkmès ir daiktų kaitos kontempliacijai, wabi-sabi estetikos bruožai atsiskleidè ivairiuose japonų kasdienybès fragmentuose, kuriuos laikome reprezentacinèmis šios kultūros formomis - honkoyoku arba tradicinèje Skakunaki klajojančiu dzen vienuolių muzikoje, ikebanoje (gèlių aranžavime), japoniškuose soduose (dzen arba bonsai medžių soduose), japonu poezijoje, keramikoje (Hagi ware, 
Raku ware), arbatos gėrimo ceremonijoje. Kaip pažymi Schaefferis, „,arbatos ceremonija ar ikebana yra tokios pačios svarbos menas Japonijoje kaip poezija ar tapyba. Arbatos ceremonijos atvejis yra ypač svarbus, nes jis rodo, kad netgi kukliausia ir banaliausia žmogaus veikla gali būti stilizuota ir pakylèta į itin sudètinga jautrų ir labai rafinuotą išgyvenimą teatrinëje estetikoje, tradiciniame japonu dizaine, asketiškame jo kompozicijos, spalvos, išraiškingos detales suvokime ${ }^{\text {«20 }}$.

Wabi-sabi susijusi su jusliniu daiktu kokybiu suvokimu, minètosios kategorijos savybiu turintys daiktai priartina mus prie esminių tiesų: daiktai dažniausiai seniai naudoti, nebenauji, dažnai padengti patinos, subraižyti, suskaldyti, praradę savo buvusią spalvą. Visada tokiuose daiktuose jaučiamas saulès, lietaus, vejjo, šalčio poveikis, negana to - jie dažnai būna surūdiję, aplūžę, isskilę. Jie atgyja naujam gyvenimui ir, paimti į rankas, pradeda pasakoti savo istoriją. ,Wa$b i$-sabi išplěšia mus iš kasdienio pasaulio suvokimo, nes neatitinka iprasto grožio idealo. Atrodo, kad jie netinka prie bendro vaizdo ir taip sukuria erdvę naujam aplinkos ir pagaliau mūsų pačių stebejjimo būdui. ${ }^{21}$

\section{IŠVADOS}

Gaustai aptarę čan atspindžius japonų dzen estetinių idealu paveiktoje wabisabi estetikoje, joje išvystame naujomis semantinèmis prasmèmis praturtintus šintoistinès panestetinès pasaulejjautos peddsakus. Šintoizmas japonų dzen estetikos ir meno tradicijai suteikè ypatingą stiliaus rafinuotumą ir imlumą žmogu supančio gamtos pasaulio grožiui. Kita vertus, dèl iš Kinijos atkeliavusių čan estetikos ideju ir sąvokų poveikio japonu kultūros, estetinès minties ir meno raidoje įsigalëjo griežtos askezės, atsiskyrèliško kontempliavimo, vidinès rimties, intymios harmonijos su gamta ieškojimo nuostatos. Jos stiprino introspekcijos tendencijas, atsiribojimą nuo išorinių būties formu ir skatino pažinti po išoriniu regimybės sluoksniu slypinčias gelmines daiktų ir reiškinių esmes.

Tuštuma, jos pasireiškimas kaip visa apimančios ir tuo pačiu neturinčios formos, čia suvokiama kaip pasaulio susi- kūrimo pagrindas, nes dzenbudizme nuolatiniu zazen praktikavimu buvo galima pasiekti satori, kuri išlaisvina žmogaus mąstymo galią ir atveria daiktu tikrosios prigimties suvokimo prasmes, t. y. priartina prie pirmapradès būties slépinių. Būdami krikščioniškojo pasaulio atstovai, sunkiai priimame pasaulio kaip Tuštumos įvaizdi, kuris yra visa ko pradžia, ikūnijanti Absoliutaus prado esmę. Tačiau Rytu Azijos budizmo adeptui, ipratusiam prie kitokiu vaizdiniu pasaulio, kaip visa kuriančios, metafiziškai suvokiamos erdvès, siejimas su neišsemiama Tuštuma atrodo tiek pat iprastas kaip ir krikščionio tikejjimas kažkur visatoje egzistuojančiu rojaus vaizdiniu.

Ir galiausiai, pasauli suvokiant juslèmis, japonų estetinè sąmonè tiesiogiai susiduria su neišsakomumo principu, kuris vèliau, dzenbudizmui sąveikaujant su šintoizmo sąlygota wabi-sabi estetika, tampa neatsiejama dzen tradicijos meni- 
ninko kūrybinės raiškos dalimi, o non finito principas - vienu svarbiausių skiriamujuc dzen meno bruožų. Negana to, lygiai taip pat ir menininkas tampa visuminès Tuštumos dalimi ir yra neišsakomas, kaip ir pati būtis, jo kūrybos rezultatai yra suvokiami intuityviai, atsiduodant empiriškai neapčiuopiamam menininko ir kosmoso (tobulosios dar-

\section{Literatūra ir nuorodos}

1 Dalia Švambaryte, Japonijos istorija. Vilnius: BMK leidykla, 2016, p. 251.

2 Antanas Andrijauskas, Tradicine japonu estetika ir menas. Vilnius: Vaga, 2001, p. 119.

3 Vaizdo įrašas: Lina Gotautė, Japonų estetinių kategorijų wabi ir sabi sklaida Kamakuros epochoje, Filosofija.INFO, paskelbta: $20151123<$ https:// www.youtube.com/watch?v=k_f4W221DP4>.

4 Leonard Koren, Wabi-Sabi for Artists, Designers, Poets and Philosophers. Berkeley: Stone Bridge Press, 1998.

5 Andrew Juniper, Wabi-sabi: The Japanese Art of Impermanence. North Clarendon: Tuttle Publishing, 2003.

6 Richard R. Powell, Wabi-sabi Simple. Avon: Adams Media, 2004.

7 Taro Gold, Living Wabi Sabi - The True Beauty of Your Life. Kansas City: Andrews McMeel Publishing, 2004.

8 Tadao Ando, What is wabi-sabi? <http://www. nobleharbor.com/tea/chado/WhatIsWabi-Sabi. htm> [žiūrèta 201710 07].

9 Ten pat.

10 Junichiro Tanizaki, In Praise of Shadows. New Haven: Leete's Island Books, 1977, p. 11.

11 George Bailey Sansom, Short Cultural History. Tokyo: Charles E. Tuttle, 1973, p. 341-342. nos) ryšiui. Iš čia plaukia japonų estetikos tradicijai būdingas atidumas nuolatos besikeičiančioms gamtos grožio apraiškoms, harmoningas ir nedalomas, i metų laikų tėkmę îsiklausantis ir kasdieniais ritualais palaikomas namų ir juos supančios aplinkinès erdvès suvokimas lemia wabi-sabi estetikos jauseną puoselèjančią kultūrą.

12 Teitarō Daisets Suzuki, The Buddhist Conception of Reality, The Buddha Eye: An Anthology of the Kyoto School and Its Contemporaries. Ed. Frederick Franck. Bloomington: World Wisdom, 2004, p. 86.

13 Antanas Andrijauskas, Neklasikinés ir postmodernistines filosofijos metamorfozès. Vilnius: Meno rinkos agentūra, 2010, p. 595.

14 Ten pat, p. 595.

15 Abe Masao, God, Emptiness and True Self, The Buddha Eye: An Anthology of the Kyoto School and Its Contemporaries. Ed. Frederick Franck. Bloomington: World Wisdom, 2004, p. 64.

16 Ten pat, p. 65.

17 Teitarō Daisets Suzuki, Self the Unattainable, The Buddha Eye: An Anthology of the Kyoto School and Its Contemporaries. Ed. Frederick Franck. Bloomington: World Wisdom, 2004, p. 3.

18 Ten pat, p. 4.

19 Roland Barthes, L'Empire des signes, Genève: Albert Skira, 1970, p. 20.

20 Jean-Marie Schaeffer, Plaisir et jugement, L'art sans compas. Paris: 1992, p. 31.

21 Christopher A. Weidner, Vabi Sabi netobulas, tačiau laimingas Azijietiškas kelias $i$ vidine ramybę. Iš vokiečių $\mathrm{k}$. vertė Irena Zabukienè. Vilnius: Algarvè, 2008, p. 34. 